\title{
Changes of properties of engine oils diluted with diesel oil under real operating conditions
}

The aim of the article was to analyze changes in the trends of selected physical, chemical and functional properties of lubricating engine oil operating in a diesel-engine vehicle equipped with DPF. The vehicle was operated mainly in urban driving conditions (app. 70\%), which impeded the DPF regeneration cycle and caused dilution of oil with unburned fuel. Changes in the following physical and chemical properties were assessed: the DF level in engine oil, viscosity (kinematic, dynamic HTHS and structural CCS), total base number, acid number as well as the degree of oxidation, nitration and sulphonation. The tests have shown that the amount of unburned fuel that goes to the engine crankcase due to the unfinished DPF regeneration cycle is as high as 26.0-34.6\%. Dilution of the lubricating oil with fuel leads to a significant reduction of its viscosity - about $30 \%$ of the fuel content causes a decrease in the kinematic viscosity measured at $100^{\circ} \mathrm{C}$ to the level of $7.7 \mathrm{~mm}^{2} / \mathrm{s}$. There was also a significant decrease in total base number (TBN) $<2 \mathrm{mg} \mathrm{KOH} / \mathrm{g}$, and an increase in the total acid number (TAN). Moreover, the results obtained were analyzed for potential effects that could have been caused during prolonged engine operation by assessing the content of trace elements in the samples taken.

Key words: oil condition monitoring, lubricant properties, DPF, degradation, reliability, dilution of the lubricating oil

\section{Introduction}

Increasingly stricter standards in the field of environmental protection have led, as far as compression ignition engines (CI) are concerned, to the widespread distribution of diesel particulate filters (DPFs), which require at least periodic regeneration processes to function properly. In the case of an LD (Light Duty) engine it is common practice to actively regenerate plus apply an additional fuel dose injected by the high pressure fuel injection system at the end of the combustion stroke so that, as a result of combustion in the exhaust system, the exhaust gas temperature increases before it reaches DPF [18]. The high temperature corrosion effect is also expected during the demanding regeneration phases, when temperature peak values on some DPFs substrates eventually exceed $1200^{\circ} \mathrm{C}$ [7]. Unfinished cycles of filter regeneration lead to the penetration of excess unburned fuel into the engine oil, which results in a significant deterioration of its physical, chemical and functional properties. The viscosity of the lubricating oil is systematically lowered as a result of diluting it with fuel and the leaching of elements included in the additives package follows. This contributes to an accelerated reduction of the base number, with the simultaneous increase in the acid number of the lubricating oil. Sejkorova et al. [16] singled out two factors influencing the durability of engine oils and loss of the functional properties of lubricating systems. The first is degradation - thermal and oxidative, as a result of a decrease in anti-oxidant, anti-abrasive and detergent additives efficiency owing to the destruction of polymer viscosity modifiers. The other is contamination with combustion products, due to solid particles such as dust, outer contaminants, abrasive metals, water and cooling liquid as well as to diluting the oil with unburned fuel.

The aim of this article is to analyze change trends in selected physical, chemical and functional properties of lubricating engine oil as a result of app. $70 \%$ urban operation (driving and stoppages in traffic jams, driving on relatively short distances without heating the engine, repeated heating and cooling as well as multiple cycles of a cold engine, which are very harmful for both the oil and diesel particulate filter) in a diesel-engine vehicle equipped with DPF after the dilution of oil (about 30\% Diesel Fuel - DF, measured after the operation phase) with unburned fuel. Changes in the following physical and chemical properties occur: DF level in engine oil, viscosity (kinematic, dynamic HTHS and structural CCS), total base number, acid number as well as the degree of oxidation, nitration and sulphonation. The results obtained were analyzed for potential effects that could have been caused during prolonged engine operation by assessing the content of trace elements in the samples taken. In the literature on the subject many scientists have investigated the changes in the properties of engine oils under real operating conditions. Sejkorova and Glos [14] conducted an analysis of the degradation of engine oils used in Zetor tractors which showed that the lubrication and friction processes in their engines were affected negatively which resulted in increased wear. Bulsara et al. [5] predicted about the residual life of lubricant oil in a four stroke engine. Severa et al. [17] dealt with the evaluation of changes in the flow of oil in motorcycle engines during their life cycle. Wolak and Zając [22] developed a statistical model enabling to calculate average predictive values of kinematic viscosity for a given mileage under similar operating conditions. Naikan et al. [12] proposed a procedure (statistical models 'fitted' to experimental data) for reliability analysis of oil used for engine lubrication in wheeled vehicles. Sejkorova et al. [15] presented the results of tests on two types of used engine oils from two different suppliers. The evaluation of selected parameters did not prove that after the exceeding of $40,000 \mathrm{~km}$ oil change interval the more expensive engine oil would ensure all the required functions as it had been declared by the supplier's sales representative. Kral et al. [9] tested long-life engine oils (the engine oil change intervals for those cars are somewhere between 30,000 and $50,000 \mathrm{~km}$ ) used in unfavourable or difficult conditions. However, the results they ob- 
tained did not correspond to onboard computer readings. Many scientists have proposed the use of various sensors to control the quality of engine oil during the engine operation $[1,4,8,21]$. However, the problem with using engine operating parameters is that they do not monitor the physical properties of the lubricant directly, therefore critical problems such as fuel contamination, can be overlooked. Diluting engine oil with fuel can cause very dangerous effects to the engine, including occurrence of boundary lubrication, accelerated wear of cylinder liners, piston rings, bearings and crank pins, reduction of lubricating oil pressure, reduction of engine performance or, ultimately, reduction of engine's life time [19].

\section{Characteristics of the research material}

The experimental materials were engine oils in the viscosity class SAE $0 \mathrm{~W} 40$ and $5 \mathrm{~W}-30$ and the quality ACEA 2016 - C3 (coded as CE and PE). The level of changes was assessed in the properties of oil used in the BMW model 520 vehicle, equipped with self-ignition engine, driven by the same manufacturer's fuel.

Table 1 contains the general specification of the selected model. Before starting the operation, the output parameters for the sample of unused (fresh) engine oil were determined, and then the same test cycle was carried out five times every $15,000 \mathrm{~km}$ (details in Table 2). During the experiment, three samples of CE oil and two samples of PE oil were obtained. No refills were used. To the contrary, oil surplus in the lubrication system under the inflow of DF was a real problem.

Table 1. The general specification of the BMW 520 D

\begin{tabular}{|l|c|}
\hline Production year & 2006 \\
\hline Engine displacement & $1995 \mathrm{~cm}^{3}$ \\
\hline Engine type & diesel \\
\hline Engine power & $120 \mathrm{~kW}$ at $4000 \mathrm{rpm}$ \\
\hline Maximum torque & $340 \mathrm{Nm}$ at $2000 \mathrm{rpm}$ \\
\hline Forced induction & by turbocharger (gas compressor) \\
\hline Number of cylinders & straight (inline) \\
\hline Cylinder arrangement & 16 \\
\hline Number of valves & Common Rail \\
\hline Injection type & $5.5 \mathrm{dm}^{3}$ \\
\hline Lubrication system capacity & 6 -gear \\
\hline Manual gearbox & rear axle \\
\hline Transmission type & \\
\hline
\end{tabular}

Table 2 lists the oils selected for testing in the viscosity class SAE 0W-40 and 5W-30 together with the API, ACEA requirements specified by the manufacturer as well as the requirements of the engine makers.

When analyzing the obtained results of engine oil properties it should be taken into account that the vehicle was operated in $70 \%$ in the urban cycle and in $30 \%$ in the nonurban cycle. The actual operating conditions of the vehicle in the urban cycle involved:

- operation of the car requiring a large, variable load on the engine (alternating, rapid acceleration and deceleration, driving with heavy load),

- prolonged engine idling (driving and stoppages of the car in traffic jams),

- driving the car on short distances using an unheated engine,
- frequent starts at low engine temperatures.

Table 3 presents the details related to the operation of the test facility containing engine oil.

Table 2. Quality and viscosity classification of engine oils selected for testing

\begin{tabular}{|l|l|l|l|l|}
\hline $\begin{array}{l}\text { Oil } \\
\text { Code }\end{array}$ & SAE & ACEA & API & $\begin{array}{l}\text { Classification according to } \\
\text { engine manufacturers }\end{array}$ \\
\hline CE & 0W-40 & C3 & SN & $\begin{array}{l}\text { BMW Longlife-04, dexos2®*, } \\
\text { Meets Fiat 9.55535-S2, MB- } \\
\text { Approval 229.31/ 229.51, Por- } \\
\text { sche A40, Renault RN 0700 / } \\
\text { RN 0710, VW 502 00/505 00 }\end{array}$ \\
\hline PE & 5 W-30 & C3 & - & $\begin{array}{l}\text { VW Standard 504 00/ VW } \\
\text { Standard 507 00, Mercedes-Benz } \\
\text { 229.51, BMW Longlife-04, } \\
\text { Porsche C30, Audi, Skoda, Seat }\end{array}$ \\
\hline
\end{tabular}

Table 3. Operational characteristics of the test facility

\begin{tabular}{|l|c|c|c|}
\hline Sample code & $\begin{array}{c}\text { Initial car } \\
\text { mileage } \\
{[\mathrm{km}]}\end{array}$ & $\begin{array}{c}\text { Car mileage / } \\
\text { sampling [km] } \\
\text { (date) }\end{array}$ & $\begin{array}{c}\text { Number of kilo- } \\
\text { meters driven } \\
{[\mathrm{km}]}\end{array}$ \\
\hline $\begin{array}{l}\text { CE 1; Sample } \\
\text { One }\end{array}$ & 130600 & $\begin{array}{c}147000 / \\
(21.07 .2013)\end{array}$ & 16400 \\
\hline $\begin{array}{l}\text { CE 2; Sample } \\
\text { Two }\end{array}$ & 147000 & $\begin{array}{c}164085 / \\
(30.04 .2014)\end{array}$ & 17085 \\
\hline $\begin{array}{l}\text { CE 3; Sample } \\
\text { Three }\end{array}$ & 164085 & $\begin{array}{c}180400 / \\
(15.06 .2015)\end{array}$ & 16315 \\
\hline $\begin{array}{l}\text { PE 1; Sample } \\
\text { One }\end{array}$ & 180400 & $\begin{array}{c}196300 / \\
(23.05 .2016)\end{array}$ & 15900 \\
\hline $\begin{array}{l}\text { PE 2; Sample } \\
\text { Two }\end{array}$ & 196300 & $\begin{array}{c}206900 / \\
(02.03 .2017)\end{array}$ & 10600 \\
\hline
\end{tabular}

\section{Methods of research}

In order to ensure the required physical, chemical and functional properties of lubricating oil during operation, in recent years procedures for their monitoring have been developed and widely applied. Detailed verification of oil change intervals is carried out depending on the operating conditions, which are closely related to both the quantitative and qualitative lubricating oil degradation processes.

Considering the above-presented issues, the focus was on assessing the changes in physical, chemical and functional properties affecting the operational usefulness of motor oils, i.e. viscosity (kinematic, dynamic HTHS and structural CCS), total base number, acid number, DF content and oxidation, nitration and sulfonation. The kinematic viscosity was calculated on the basis of the flow time, specific volume of liquid by the calibrated capillary (Ubbelohde capillary viscometer), under strictly defined measurement conditions (flow time, capillary constant etc.) and at the strictly determined temperature, according to the EN ISO 3104 standard. Dynamic viscosity HTHS (high temperature high shear) was determined at $150^{\circ} \mathrm{C}$ at the shear rate of $10^{6} \mathrm{~s}^{-1}$, using the Ravenfield viscometer with coaxial cones, in accordance with the ASTM D4741 standard. The determination of structural viscosity at low temperatures was carried out according to the PN-C-04150:2004 standard by means of a cold cranking simulator, by measuring the rotational speed of the impeller immersed in oil cooled down to $-35^{\circ} \mathrm{C}(\mathrm{CE})$ and $-30^{\circ} \mathrm{C}(\mathrm{PE})$. The content of acidic substances (ASTM D664) and weak bases in the paraffin products was measured by the potentiometric titration method. The measure unit of their content is the so-called total base number, also referred to as the alkaline reserve 
(ASTM D2896). The determination of diesel oil content in engine oil was performed by capillary gas chromatography with FID flame-ionization detection. The capillary column used, with an average film thickness of the dimethylpolysiloxane stationary phase, enabled the separation of the diesel oil and engine oil fractions. Using the infrared spectroscopy method (ASTM E2413 A.2), the oil aging process was monitored, which occurs under operating conditions due to three processes: oxidation (binding of oxygen to hydrocarbons contained in oil), sulfonation (binding of sulfur oxides) and nitration (binding of nitrogen oxides). On the basis of the nature of the operated oil spectrum, the signal measurement was analyzed in a specific area of infrared radiation absorption. The levels of the previously discussed carbonyl, nitro and sulphonic groups for used oils were determined not directly from their spectra, but from the difference spectra, i.e. the spectra resulting from the mathematical operation: the spectrum of used oil minus the spectrum of fresh oil. The contents of elements derived from the additives and of metals which polluted the oil due to the wear of engine components, were determined by the ICP-OES technique in an environment of organic solvents using the internal standard method, according to the ASTM D 5185 method.

\section{Presentation and analysis of test results}

Figure 1 shows the diesel oil content in the analyzed engine oil lubricating samples. Definitely more fuel was found in oils from the CE group (on average $34.6 \%(\mathrm{~m} / \mathrm{m})$ ) than from the PE group (on average $26 \%(\mathrm{~m} / \mathrm{m})$ ). The most DF was found in the CE1 sample and it was a very dangerous level of $37.1 \%(\mathrm{~m} / \mathrm{m})$.

Booser [3] indicates possible condemning limits for fuel contamination: minor (1.5-4.5\%), significant (5-7.5\%) and excessive (> 7.5\%). Excessive lubricant contamination may lead to dramatic changes in lubricant properties, preventing the lubricant from performing its required functions [6]. The low level of DF in the lubricating oil in PE2 sample can be explained by the lowest mileage of the vehicle $(10,600 \mathrm{~km})$.

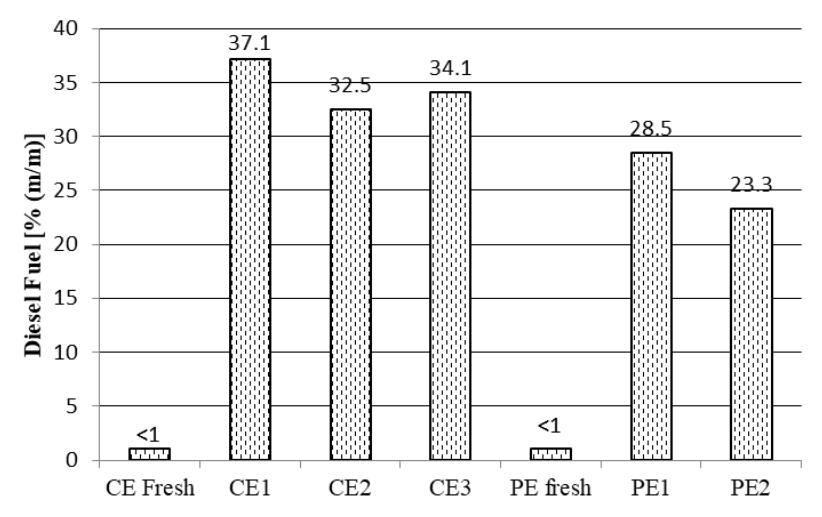

Fig. 1. Change of diesel fuel content in engine oil during operation

Increased dilution of engine oil with diesel fuel is attributed to the use in common rail injection systems of the software supporting the regeneration of diesel particulate filters by means of additional fuel injection after completing the combustion process [19]. If the process is not com- pleted, due to random occurrences during the DPF regeneration cycle, there is an increased penetration of fuel into the engine oil. This is most often the case during the urban driving cycle.

The high diesel fuel content in the tested samples is confirmed by a significant decrease in the kinematic viscosity determined at $40^{\circ} \mathrm{C}$ and $100^{\circ} \mathrm{C}$. The changes in kinematic viscosity occurring at both temperatures are presented in Fig. 2.

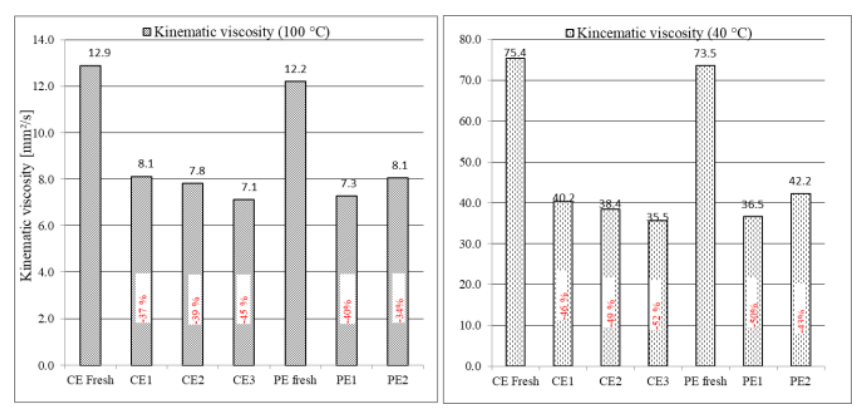

Fig. 2. Changing the kinematic viscosity in the tested lubricating oil samples

On the basis of the obtained test results it was observed that as a result of DF transfer to the engine oil there is a dangerous (about 50\%) decrease in the kinematic viscosity at $40^{\circ} \mathrm{C}$ (after the average mileage of $16,600 \mathrm{~km}$ ), the largest for CE3 samples (decrease by $52 \%$ in relation to the initial value $52 \%$ ) and PE1 (decrease by $50 \%$ ), while the lowest for: PE2 (decrease by $34 \%$ in relation to the initial value) and CE1 (decrease by $46 \%$ ). The situation is similar for the changes in the kinematic viscosity of engine oil determined at $100^{\circ} \mathrm{C}$. The viscosity value at this temperature, after the same mileage, dropped by about $40 \%$ in relation to the initial value (for the CE1 sample: by $37 \%$, CE2: by $39.3 \%$, CE3: by $44.8 \%$, PE1: by $40 \%$, PE2: by $34 \%$ ). According to the classification SAE J300 from 2015, the kinematic viscosity at $100^{\circ} \mathrm{C}$ for oils of class 40 should be in the range of $12.5-16.3 \mathrm{~mm}^{2} / \mathrm{s}$. The obtained results provide the basis for stating that the kinematic viscosity of the analyzed oil, after the average mileage of approximately $16,600 \mathrm{~km}$, drops to the levels corresponding to viscosity class 20 .

Thus, the oil is not kept in the viscosity class declared by the manufacturer (40). On the one hand, it can be considered that reducing the viscosity will bring benefits such as faster circulation in the engine and reduced energy consumption. Nevertheless, the use of viscosity class 40 oil suggests the need to better protect the engine from wear, and not reduce energy consumption, and you can have doubts whether the gap between the piston and the cylinder wall will be effectively sealed. Such a large amount of fuel in oil did not allow for the compensation of the oil viscosity decrease by the increase in viscosity resulting from the oil densification by degradation products. Attention should be drawn to the fact that both CE2 and PE1 oils underwent very similar viscosity drops at $40^{\circ} \mathrm{C}$ and $100^{\circ} \mathrm{C}$, in spite of the fact that they differed significantly in the fuel content (32.5 and 28.5) - this resulted from the fact that the CE oil should have a lower viscosity with a higher fuel content, which was not the case. The reason could be the use of 
a different set of antioxidant additives and the emergence of larger amounts of degradation products increasing viscosity. That is also confirmed by the observation of oxidation change presented in Fig. 4. The HTHS dynamic viscosity (Fig. 3) of the tested engine oil samples was not maintained at levels guaranteeing the provision of a suitable lubricating film at high temperatures and at high shear rates.
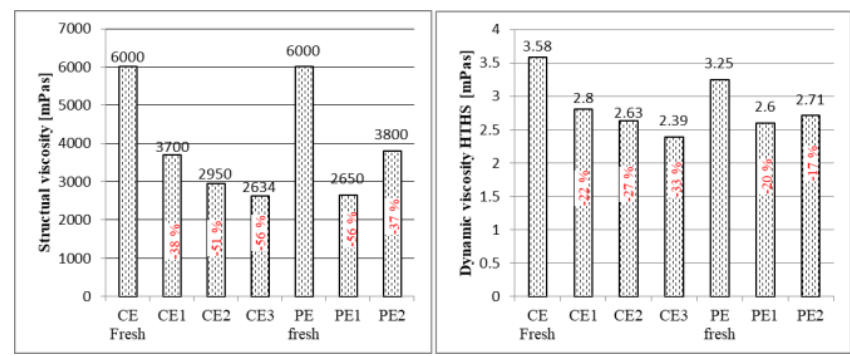

Fig. 3. Changes in dynamic viscosity - structural viscosity $\mathrm{CCS}\left(-35^{\circ} \mathrm{C}\right.$ : $\mathrm{CE},-30^{\circ} \mathrm{C}: \mathrm{PE}$ ) and HTHS

According to the SAE J300 classification, the HTHS dynamic viscosity should not be lower than $2.9 \mathrm{mPa} \cdot \mathrm{s}$. The highest decrease in HTHS viscosity occurs in relation to the CE3 sample: $33 \%$ (mileage 16,315 km), while the lowest for the PE2 sample: $17 \%$ (mileage 15,900 km). From the changes in the structural viscosity of the tested engine oils presented in Fig. 3 at $-35^{\circ} \mathrm{C}(\mathrm{CE})$ and $-30^{\circ} \mathrm{C}(\mathrm{PE})$, by the cold start simulator (CCS), it is obvious how significantly the structural viscosity of the oil gets affected under the described operating conditions. The largest decrease in structural viscosity in relation to the initial value was observed for the CE3 and PE1 samples: 56\%. For the other samples, the decrease is slightly lower, nevertheless it still remains at a significantly high level (over 37\%).

As to the indirect assessment of the oxidation stability loss of oils in a large volume, i.e. changes in the acid number (Fig. 5) and assessment of IR spectrum changes (Fig. 4 ), it was observed that in each case (for all the tested samples) the changes occurring during operation showed similar levels of engine oil degradation. CE oils were characterized by a lower resistance to oxidation (oil degradation caused by undesirable chemical reactions with oxygen) than PE oils. The value of all the tested oil samples in all the cases after an average mileage of $16,600 \mathrm{~km}$, exceeded level 1 (Abs/0.1 mm). There has been a significant increase in the degree of oxidation. It is assumed that the limit value for oxidation degree is 0.4 (Abs/0.1 mm) [19].

When assessing the reactions occurring during the contact of hydrocarbons with nitrogen oxides, resulting from the engine operation leading to the formation of organic nitrates, it was found out that after the examined mileage there was an increase in the binding of nitrogen compounds exceeding the permissible level $(0.4 \mathrm{Abs} / 0.1 \mathrm{~mm})$ for two samples (CE1 - $0.46(\mathrm{Abs} / 0.1 \mathrm{~mm})$ and CE3 - 0.48 (Abs/0.1 mm). The values of sulphonation of lubricating engine oils under the analyzed conditions stayed at an average level of about 0.16 (Abs/0.1 mm). It can be observed that the binding of sulfur compounds stayed at the highest level, 0.28 (Abs/0.1 mm), for the sample CE2, characterized by the lowest oxidation and nitration (in the group of oils CE).

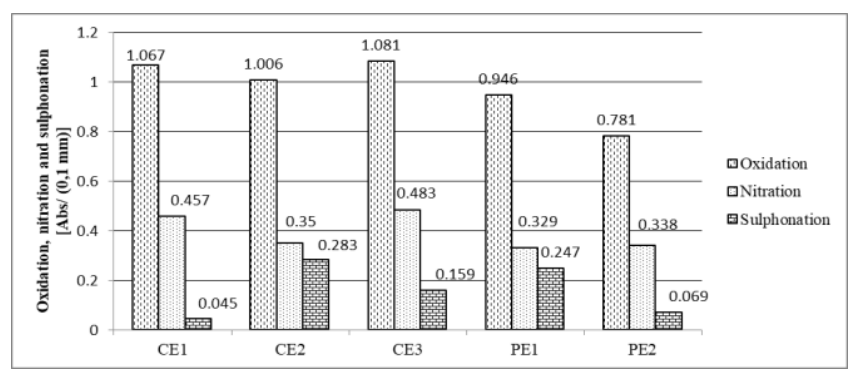

Fig. 4. Oxidation, nitration and sulphonation changes

The mixture of compounds with different physical and chemical properties as well as the group composition of engine oil affect the width of the spectrum of compounds that may be formed under operating condition. The heat generated during the engine operation, contact with fuel and its combustion products, combined with the common presence of oxygen from the air, cause the degradation of the basic engine oil component: hydrocarbons. The accompanying chemical and mechanical-chemical transformations cause a decrease in the content of additives introduced into the engine oil to give it the required quality characteristics. The acid value (Fig. 5), which for fresh oil was 2.21 (CE) and 1.95 (PE) $\mathrm{mg} \mathrm{KOH} / \mathrm{g}$, significantly increased after the operation period (the largest increase for CE3 samples $285 \%$ and for PE1 - 178\%).

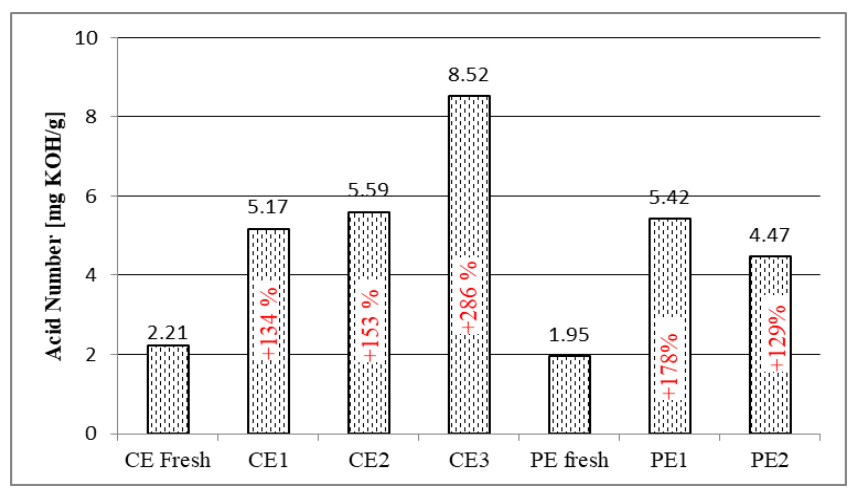

Fig. 5. Changes in the acid number of the tested engine oil samples

The changes in the total base number were equally large as the above-analyzed acid number changes.

The greatest changes were observed for the CE oil samples (over 70\%). Such a high drop can be linked to, among others, a high content of fuel, as for PE samples with lower fuel content these changes were not so high. However, it should be taken into account that differences in the drop may also result from the additive package used by the producers. Such a large decrease in the total base number is a warning signal for the owner of the vehicle, because the loss of alkaline reserve is a decrease in the lubricating oil's ability to neutralize acidic combustion products (engine oil should neutralize acidic products from fuel combustion and prevent corrosion processes). These changes will also affect the oil washing and dispersing potential, i.e. the ability of the oil to maintain any deposits in its volume and prevent their deposition on the engine's structural elements. 


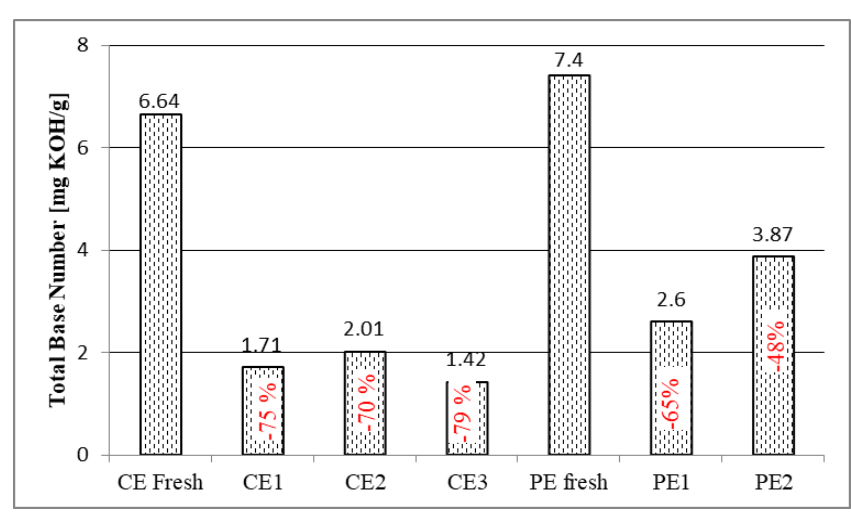

Fig. 6. Changes in the total base number in the tested engine oil samples

The next stage of the research was the assessment of trace elements content in the samples taken. Table 4 summarizes the content of metals originating from the wear processes, impurities, additives package or other aforementioned sources. The ranges of elements and wavelengths are also given.

The analysis of the content of individual chemical elements was carried out for each metal separately:

- Aluminum - wear product - piston damages, aluminum bearings, cylinder block surfaces [20]. Excessive presence can cause damage to the filter and a drop in oil pressure. In the CE2 sample a concentration of 11 $\mathrm{mg} / \mathrm{kg}$ was recorded, in the other samples the level is below the lower limit of detection.

- Iron - a significant product of wear. The sources of origin include: cylinder liners, piston rings, camshaft and crankshaft, gear teeth, water [20]. Excessive presence of iron can cause oil degradation, insufficient lubrication, corrosion, oil film breakage, abnormal operating temperature and a drop in oil pressure [11]. The highest concentration was recorded in the CE2 sample: $>140$ (259) $\mathrm{mg} / \mathrm{kg}$.

- Lead, nickel, manganese - products of wear the amount of which increases with the use of oil [20]. In the ana- lyzed samples, the presence of these elements is below the lower limit of detection.

- Potassium, sodium - classified as the pollutants [24]. The presence of these elements is below the lower limit of detection.

- Chromium - a high level of chromium may indicate excessive wear of chromed components such as rings and sleeves $[13,20]$. The highest concentration was recorded in the CE2 sample $-6.1 \mathrm{mg} / \mathrm{kg}$.

- Copper - product of wear (wear of bearings and radiator tubes), or additive [23]. The highest concentration occurs for the CE2 sample: $14 \mathrm{mg} / \mathrm{kg}$, while the average concentration for the remaining samples is $8.6 \mathrm{mg} / \mathrm{kg}$.

- Magnesium - it appears in detergent but also as a product of wear (used in the construction of bearings), its visible significant increase for the CE3 sample: 314 $\mathrm{mg} / \mathrm{kg}$. The average for the remaining samples is 7 $\mathrm{mg} / \mathrm{kg}$. In the study carried out by Zięba-Palus et al. [25] engine oils generally differed from each other in terms of magnesium content, although these differences were relatively small (in this study, however, the diversity is very high (the coefficient of variation has reached $179 \%$ ).

- Zinc - a component of an additive. It has anti-corrosive properties. The highest content was recorded in the CE3 sample: $1016 \mathrm{mg} / \mathrm{kg}$. The average for the remaining samples is $608 \mathrm{mg} / \mathrm{kg}$.

- Molybdenum - a component of an additive for engine oil. The highest content occurs in CE1 and CE3 samples $(88 \mathrm{mg} / \mathrm{kg}$ on average). The average for the remaining samples is $16 \mathrm{mg} / \mathrm{kg}$.

- Boron - a component of an additive [10]. The lowest content remained in the CE2 oil $-6.3 \mathrm{mg} / \mathrm{kg}$.

- Calcium - it may occur as an impurity or an additive [2]. The highest content is found in the CE3 sample $(2056 \mathrm{mg} / \mathrm{kg})$. The average for the remaining samples is $1114 \mathrm{mg} / \mathrm{kg}$.

Table 4. Content of trace elements in the collected samples

\begin{tabular}{|c|c|c|c|c|c|c|c|c|c|}
\hline & & & & & \multicolumn{5}{|c|}{$\mathrm{C} \pm \mathrm{U}[\mathrm{mg} / \mathrm{kg}]$} \\
\hline Element & $\begin{array}{c}\text { Range } \\
{[\mathrm{mg} / \mathrm{kg}]}\end{array}$ & $\begin{array}{c}\text { Wave } \\
\text { length }[\mathrm{nm}]\end{array}$ & $\begin{array}{c}\text { Fresh } \\
\text { CE }\end{array}$ & $\begin{array}{l}\text { Fresh } \\
\text { PE }\end{array}$ & $\begin{array}{c}\text { Sample } \\
\text { CE 1 }\end{array}$ & $\begin{array}{l}\text { Sample } \\
\text { CE } 2\end{array}$ & $\begin{array}{l}\text { Sample } \\
\text { CE } 3\end{array}$ & $\begin{array}{c}\text { Sample } \\
\text { PE 1 }\end{array}$ & $\begin{array}{l}\text { Sample } \\
\text { PE 2 }\end{array}$ \\
\hline \multicolumn{10}{|c|}{ Metals from wear processes } \\
\hline $\mathrm{Al}$ & $6.0-40$ & 167.078 & $<6.0$ & $<6.0$ & $<6.0(5.7)$ & $11 \pm 5$ & $<6.0(3.1)$ & $<6.0(5)$ & $<6.0(4.8)$ \\
\hline $\mathrm{Fe}$ & $2.0-140$ & 259.941 & $<2.0$ & $<2.0$ & $128 \pm 18$ & $>140(259)$ & $16 \pm 3$ & $95 \pm 14$ & $50 \pm 8$ \\
\hline $\mathrm{Pb}$ & $10-160$ & 220.353 & $<10$ & $<10)$ & $<10$ & $<10$ & $<10$ & $<10$ & $<10$ \\
\hline $\mathrm{Mn}$ & $5.0-700$ & 257.611 & $<1.0$ & $<1.0)$ & $<5.0$ & $<5.0$ & $<5.0$ & $<5.0$ & $<5.0$ \\
\hline $\mathrm{Ni}$ & $5.0-40$ & 231.604 & $<5.0$ & $<5.0$ & $<5.0$ & $<5.0$ & $<5.0$ & $<5.0$ & $<5.0)$ \\
\hline \multicolumn{10}{|c|}{ Metals from the contamination of oil } \\
\hline $\mathrm{K}$ & $40-1200$ & 766.491 & $<10.0$ & $<10.0$ & $<10$ & $<10$ & $<10$ & $<10$ & $<10$ \\
\hline $\mathrm{Na}$ & $7.0-70$ & 589.592 & $<7.0$ & $<7.0$ & $<7.0$ & $<7.0$ & $<7.0$ & $<7.0$ & $<7.0$ \\
\hline \multicolumn{10}{|c|}{ Metals from wear processes and additives package } \\
\hline $\mathrm{Cr}$ & $1.0-40$ & 267.716 & $<1.0(0.1)$ & $<1.0(0.1)$ & $3.1 \pm 1.2$ & $6.1 \pm 1.7$ & $<1.0(0.85)$ & $2.9 \pm 1.1$ & $2.1 \pm 0.9$ \\
\hline $\mathrm{Cu}$ & $2.0-160$ & 324.754 & $<2.0(0)$ & $<2.0(0)$ & $9.6 \pm 1.6$ & $14 \pm 2$ & $8.4 \pm 1.4$ & $8.8 \pm 1.5$ & $7.4 \pm 1.3$ \\
\hline $\mathrm{Mg}$ & $5.0-1700$ & 279.553 & $5.10 \pm 1.8$ & $6.26 \pm 2.1$ & $6.6 \pm 2.2$ & $8.9 \pm 2.8$ & $314 \pm 43$ & $6.5 \pm 2.2$ & $6.21 \pm 2.1$ \\
\hline $\mathrm{Zn}$ & $60-1600$ & 213.856 & $800 \pm 93$ & $833 \pm 97$ & $537 \pm 60$ & $632 \pm 71$ & $1016 \pm 120$ & $599 \pm 67$ & $665 \pm 76$ \\
\hline Mo & $5.0-200$ & 202.095 & $163 \pm 16$ & $153 \pm 16$ & $93 \pm 11$ & $14 \pm 3$ & $83 \pm 11$ & $12+ \pm 3$ & $23 \pm 4$ \\
\hline \multicolumn{10}{|c|}{ Metals from additives package and from the contamination of oil } \\
\hline $\mathrm{B}$ & $4.0-30$ & 249.773 & 171 & 171 & $29 \pm 10$ & $6.3 \pm 9.5$ & 54 & 32 & 45 \\
\hline $\mathrm{Ca}$ & $40-9000$ & 317.933 & $1812 \pm 184$ & $1797 \pm 182$ & $961 \pm 81$ & $1018 \pm 87$ & $2056 \pm 217$ & $1148 \pm 102$ & $1329 \pm 123$ \\
\hline $\mathrm{Si}$ & $8.0-50$ & 251.612 & $<8.0(4.7$ & $<8.0(4.7)$ & $8.6+/-4.8$ & $8.4 \pm 4.7$ & $<8.0(4.6)$ & $<8.9(4.9)$ & $<8.0(6.6)$ \\
\hline $\mathrm{P}$ & $10-1000$ & 177.495 & $671 \pm 80$ & $517 \pm 70$ & $403 \pm 62$ & $472 \pm 67$ & $802 \pm 87$ & $456 \pm 66$ & $517 \pm 70$ \\
\hline
\end{tabular}


- Silicon - it comes from an anti-foaming oil additive or is part of dust particles intruding into the oil from the outside (higher concentration signals a need for maintenance with the probability of air filter failure [15]. Silicon values above $8 \mathrm{mg} / \mathrm{kg}$ have been determined for CE1 and CE2 samples.

- Phosphorus - a component of an additive that provides anti-rust properties [11]. In the three samples, there was a decrease in the level of this element, which indicates its depletion during operation. On the other hand, in the case of the CE3 sample, there was an increase in relation to fresh oil $(802 \mathrm{mg} / \mathrm{kg})$, while for PE2 oil the level remained at the fresh oil level.

The analysis of trace elements content in engine oils that were diluted with fuel during operation has not given a definite answer as to the effect of fuel on their content. The observed changes in the concentration of elements did not form a clear trend. Considering that each oil sample is undergoing a different degradation process, changes can occur at various time intervals.

For the CE oil, in the second period an increase was recorded of typical wear elements: $\mathrm{Al}, \mathrm{Fe}, \mathrm{Cr}, \mathrm{Cu}$. In the third measurement period for this oil, the maximum values of $\mathrm{Mg}, \mathrm{Zn}, \mathrm{B}, \mathrm{Ca}, \mathrm{P}$ were observed with the simultaneous maximum decrease in kinematic, structural and dynamic viscosity, maximum increase in acid number and maximum decrease in base number. At the same time it could be observed that for the PE2 sample with the lowest fuel content (and mileage) the content of wear elements was at the lowest level. It should also be taken into account that the content of trace elements is connected with the dilution intensity. During the research for each of the samples this process looked different, which was due to the nature of driving and ambient temperatures during operation.

\section{Conclusion}

The tests have shown that the amount of unburned fuel that goes to the engine crankcase due to the unfinished DPF regeneration cycle is as high as 26-34.6\%. Such a large amount of fuel in oil causes its dilution. Dilution of the lubricating oil with fuel leads to a significant reduction of its viscosity - about $30 \%$ of the fuel content causes a decrease in the kinematic viscosity measured at $100^{\circ} \mathrm{C}$ to the level of $7.7 \mathrm{~mm}^{2} / \mathrm{s}$. The kinematic viscosity measured at $40^{\circ} \mathrm{C}$ showed a decrease of approximately $50 \%$ (after an average mileage of $16,600 \mathrm{~km}$ ) - the largest for samples:
CE3 (decrease by $52 \%$ in relation to the initial value) and PE1 (decrease by 50\%), and the lowest for: PE2 (decrease by $34 \%$ in relation to the initial value) and CE1 (decrease by $46 \%$ ). The dilution of oil also contributed to about a $48 \%$ decrease in structural viscosity and a $25 \%$ decrease of HTHS. Such large changes in viscosity make the oil film less able to handle large loads that can occur at certain points, such as the main bearings and those of the crankshaft. These changes are also visible in the concentration of trace elements in oil, especially in the CE2 sample (aluminum: $1 \mathrm{mg} / \mathrm{kg}$, Iron: $259 \mathrm{mg} / \mathrm{kg}$ ). Their potential sources are: wear of the main and crank bearing shell sliding layer, wear of plugs in the shells, seizure of pistons in cylinders, etc. However, there are differences in concentration changes in the analyzed periods of operation.

The gradual dilution of oil with fuel caused premature degradation of engine oils, due, inter alia, to the antagonistic effect of the components (not always compatible) of fuel and oil. It also caused the acceleration of the oxidation process, leading to levels significantly exceeding the limit values (CE over $1 \mathrm{Abs} / 0.1 \mathrm{~mm}, \mathrm{PE}$ about $0.8 \mathrm{Abs} / 0.1 \mathrm{~mm}$ ). There was also a significant decrease in the ability of lubricating oil to neutralize acidic combustion products: TBN $<2 \mathrm{mg} \mathrm{KOH} / \mathrm{g}$, and an increase in the acid number.

The dilution of engine oil with fuel is normal, provided that the amount of fuel does not exceed several percent [3]. The test results have shown that the dilution of engine oil with fuel from unfinished cycles of regeneration of DPF filters is a serious operational problem, especially for vehicles used in typically urban conditions. Changes in the parameters described are really significant and may involve potential accelerated engine wear. Therefore, continuous development and introduction of new methods of testing the changes in lubricating oil properties under operation, adjusted to the quality changes of products placed on the market and the conditions of their use, are indispensable.

\section{Acknowledgements}

The publication was funded by appropriations of the Faculty of Commodity Science, Cracow University of Economics, and Faculty of Production Engineering University of Life Sciences in Lublin within the framework of grants to maintain the research potential.

\section{Bibliography}

[1] AGOSTON, A., ÖTSCH, C., JAKOBY, B. Viscosity sensors for engine oil condition monitoring-Application and interpretation of results. Sensors and Actuators A: Physical. 2005, 121(2).

[2] BESSER, C., SCHNEIDHOFER, C., DÖRR, N. et al. Investigation of long-term engine oil performance using lab-based artificial ageing illustrated by the impact of ethanol as fuel component. Tribology International. 2012, 46(1).

[3] BOOSER, R.E. Handbook of lubrication. Boca Raton. Florida, 1983.

[4] BROUWER, M.D., GUPTA, L.A., SADEGHI, F. et al. High temperature dynamic viscosity sensor for engine oil

applications. Sensors and Actuators A: Physical. 2012, 173(1).

[5] BUlSARA, M.A., HINGUZ, A.D., PATEL, K. Prediction of residual life of lubricant oil in four stroke engine. Proceedings of International Conference on Advances in Materials and Product Design (AMPD 2015). 2015.

[6] CLARC, R.J. On board monitoring of engine oil. Faculty of The Graduate College in partial fulfillment of the requirements for the Degree of Master of Science of Engineering Department of Aeronautical and Mechanical Engineering Advisor: Claudia Fajardo, Ph.D., 2011.

[7] GILI, F., IGARTUA, A., LUTHER, R. et al. The impact of biofuels on engine oil performance. Lubrication Science. 2011, 23. 
[8] JAKOBY, B., EISENSCHMID, H., SCHATZ, O. et al. A multi-functional sensor for oil condition evaluation. Technisches Messen. 2001, 68(5).

[9] KRAL, J., KONECNY, B., MADAC, K. et al. Degradation and chemical change of longlife oils following intensive use in automobile engines. Measurement. 2014, $\mathbf{5 0}$.

[10] KUMBÁR, V., GLOS, J., VOTAVA, J. Monitoring of chemical elements during lifetime of engine oil. Acta Universitatis Agriculturae et Silviculturae Mendelianae Brunensis. 2014, 62(1).

[11] MALINOWSKA, M. Analiza zanieczyszczeń oleju silnikowego stosowanego w silniku Cegielski-Sulzer 3AL25/30. Zeszyty Naukowe Akademii Morskiej w Gdyni. 2014, 83.

[12] NAIKAN, V.N.A., KAPUR, S. Reliability modelling and analysis of automobile engine oil. Proceedings of the Institution of Mechanical Engineers, Part D: Journal of Automobile Engineering. 2006, 220(2).

[13] PALKENDO, J.A., KOVACH, J., BETTS, T.A. Determination of wear metals in used motor oil by flame atomic absorption spectroscopy. Journal of Chemical Education. 2014, 91(4).

[14] SEJKOROVÁ, M., GLOS, J. Analysis of degradation of motor oils used in Zetor tractors. Acta Universitatis Agriculturae Et Silviculturae Mendelianae Brunensis. 2017, 65(1).

[15] SEJKOROVÁ, M., HURTOVA, I., GLOS, J. et al. Definition of a motor oil change interval for high - volume diesel engines based on its current characteristics assessment. Acta Universitatis Agriculturae Et Silviculturae Mendelianae Brunensis. 2017, 65(2).

[16] SEJKOROVÁ, M., POKORNY, J., JILEK, P. The usage of modern instrumental methods in diagnostics of quality of operated engine oils. In: Proceedings Deterioration, De-

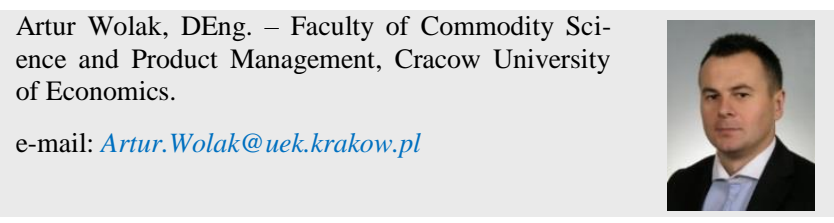

Magdalena Żółty, DEng. - Oil and Gas Institute National Research Institute, Cracow, Poland.

e-mail: Magdalena.Zolty@inig.pl pendability, Diagnostics. Brno: University of Defence. 2014.

[17] SEVERA, L., HAVLICEK, M., CUPERA, J. Changes of engine oil flow properties during its life cycle. Acta Univ. Agric. Silvic. Mendelianae Brun. 2010, 58(4).

[18] URZĘDOWSKA, W., STĘPIEŃ, Z. Olej silnikowy a biopaliwa - współdziałanie w eksploatacji. Nafta-Gaz. 2010, 10.

[19] URZĘDOWSKA, W., STĘPIEŃ, Z. Wybrane zagadnienia dotyczące zmian właściwości silnikowego oleju smarowego w eksploatacji. Nafta-Gaz. 2012, 12.

[20] VASANTHAN, B., DEVARADJANE, G., SHANMUGAM, V. Online condition monitoring of lubricating oil on test bench diesel engine \& vehicle. Journal of Chemical and Pharmaceutical Sciences. 2015, 9.

[21] WANG, S. Engine oil condition sensor: method for establishing correlation with total acid number. Sensors and Actuators B: Chemical. 2002, 86(2-3).

[22] WOLAK, A., ZAJĄC, G. The kinetics of changes in kinematic viscosity of engine oils under similar operating conditions. Eksploatacja i Niezawodnosc - Maintenance and Reliability. 2017, 19(2).

[23] YUNUS, S., RASHID, A.A., LATIP, S.A. et al. Comparative study of used and unused engine oil (perodua genuine and castrol magnatec oil) based on property analysis basis. Procedia Engineering. 2013, 68.

[24] ZAJĄC, G., SZYSZLAK-BARGŁOWICZ, J., SŁOWIK, T. et al. Designation of chosen heavy metals in used engine oils using the XRF method. Polish Journal of Environmental Studies. 2015, 24.

[25] ZIĘBA-PALUS, J., KOSCIELNIAK, P. An analysis of the similarity of motor oils on the basis of their elemental composition. Forensic Science International. 2000, 112.

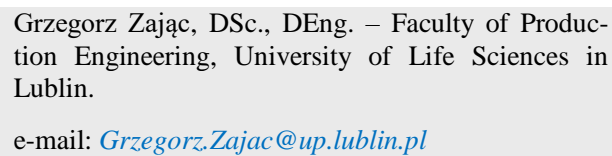

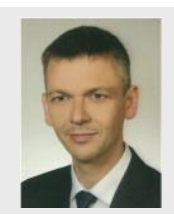

